\title{
Isolation of Mycoplasmas from Fantail Pigeons
}

\author{
Hiroshi NAGATOMO, Hiroki KATO, Takamasa SHIMIZU, and Bou KATAYAMA ${ }^{1)}$ \\ Division of Veterinary Science, Faculty of Agriculture, Miyazaki University, Gakuen-Kibanadai, Miyazaki 889-21, ${ }^{1)}$ Phoenix Natural \\ Zoo, Miyazaki 880, Japan
}

(Received 18 September 1996/Accepted 21 January 1997)

ABSTRACT. Isolation of mycoplasmas from the oropharynxes of 60 fantails reared under natural conditions at different zoological parks in Miyazaki prefecture was carried out. Mycoplasma columbinum, M. columborale and M. columbinasale were isolated from 28 (46.7\%), 22 $(36.7 \%)$, and $1(1.7 \%)$ of 60 oropharynxes, respectively, but no Mycoplasma was isolated from 5 cloacas tested. Ureaplasma was not isolated from any of the 28 oropharynxes or 5 cloacas examined. We report that $41(68.3 \%)$ of 60 fantails had one or two species of mycoplasmas in their oropharynxes, and make the first confirmation of M. columbinasale inhabiting a Japanese pigeon. - KEY wORDS: fantail pigeon, mycoplasma.

J. Vet. Med.Sci. 59(6): 461-462, 1997

In 1978, two new species of Mycoplasma, M. columbinum and $M$. columborale were isolated from feral pigeons and designated [10]. Thereafter, it was confirmed that these species of Mycoplasma were specific to pigeons, as reported by Shimizu et al. [11]. In 1982, another strain which had previously been identified as a serotype-L of avian mycoplasmas [4, 5, 8, 10-13], was designated as $M$. columbinasale [3]. M. columbinasale was isolated from pigeons in the United States of America [5], England [6, 12] and Australia [9], and from chickens in India [1]. Sinclair [12] reported a respiratory disease associated with $M$. columbinasale in racing (homing) pigeons. However, reports concerning the isolation of this organism have not been published in Japan till this study.

In this study, we tried to isolate mycoplasmas from 60 oropharynxes and 5 cloacas, as well as Ureaplasma from 28 oropharynxes and 5 cloacas of 60 healthy fantail pigeons which had been introduced to parks through bird shops in this country 20 to 25 years ago. Fantail pigeons naturally inhabit two large scale zoological parks in Miyazaki city. Located by the seashore, the climate is mild, and the fantail pigeons are freely in contact with hens, turkeys, parakeets, peafowls and galeenies through feeds and drinking water. All the birds are fed with market feeds for the hen and the drinking water contained no antimicrobial agents. Swab samples were taken when the fantail pigeons returned to rest in their hut at night. Edward's liquid and solid media were used for the isolation, subculture and biochemical tests. The liquid medium was composed of Mycoplasma broth base (Difco), 20\% fresh horse serum, 10\% yeast extract, $0.5 \%$ glucose, $0.25 \%$ L-arginine, $0.025 \%$ thallium acetate, $200 \mathrm{mg}$ AB-PC (Toyo Jyozo Co., Ltd.) and $0.002 \%$ phenolred, and its $\mathrm{pH}$ was adjusted to 7.0. Solid medium (agar plate) without phenol-red was made from the liquid medium supplemented with $1 \%$ agar (Noble agar, Difco). For the isolation of Ureaplasma, Taylor-Robinson's liquid medium [7] was used. Each swab sample was put into a test tube containing $2 \mathrm{ml}$ of Edward's liquid medium, and was then well shaken by a test tube mixer (Iuchi Co., Ltd.). A portion of $25 \mu \mathrm{l}$ from each tube was inoculated and streaked on the solid medium. The agar plate was incubated at $37^{\circ} \mathrm{C}$ for 10 days in a $5 \% \mathrm{CO}_{2}$ atmosphere (Forma Scientific 3158), and the colonies developed were observed daily from the 3 rd to the 10 th day postincubation by microscopy $(40 \times$ or $100 \times)$. Colonies showing differences in shape were subjected to cloning by picking up a single colony with an agar-block, and transplanting into fresh liquid medium. After purification, the isolated strains were identified with routine biochemical tests and serological tests of the metabolism inhibition (MI) and growth inhibition (GI) [10, 11].

Three reference strains, $M$. columbinum MMP1, $M$. columborale MMP4, and M. columbinasale 694 (by courtesy of Dr. Kelton,W. H., Univ. of Massachusetts, Amherst U.S.A.) together with the isolated 3 strains, 28L, 20P and $30 \mathrm{~L}$ were used in the tests. Rabbit antisera against the 3 reference strains and 1 of the isolated strains, 30L, were prepared with suspensions of whole cells and Freund's complete adjuvant (Iatron Laboratories, Tokyo) via S.C.

Isolation of Ureaplasma was carried out by diluting a swab-broth mixture into 10 fold serial dilutions from $10^{-1}$ to $10^{-5}$, and then incubated at $37^{\circ} \mathrm{C}$ for 7 days. Color change of the liquid medium following the growth of Ureaplasma was observed daily.

The biochemical and serological properties of the 3 reference strains and the 3 isolated strains are given in Table 1. Strain 28L was identified as M. columbinum, strain 20P as $M$. columborale and strain $30 \mathrm{~L}$ as $M$. columbinasale. In total, 74 isolates were identified by the same methods, and the results are summarized in Table 2. M. columbinum alone was isolated from $5(16.7 \%)$ of 30 fantails at park F, and $13(43.3 \%)$ of 30 at park K. M. columborale alone was isolated from $4(13.3 \%)$ and $9(30 \%)$ at park $\mathrm{F}$ and $\mathrm{K}$, respectively. $M$. columbinum and $M$. columborale together were isolated concurrently from $6(20 \%)$ at park F and 3 (10\%) at park K. Additionally, M. columbinum and $M$. columbinasale together were isolated from only 1 fantail at park K. Mycoplasma was not isolated from $15(50 \%)$ oropharynxes at park $\mathrm{F}$ and $4(13.3 \%)$ at park $\mathrm{K}$. Mycoplasma was negative in 5 cloacas tested. Ureaplasma was not isolated from any of the 28 oropharynxes or 5 cloacas examined. In total, $M$. columbinum existed in 28 $(46.7 \%)$ and $M$. columborale in $22(36.7 \%)$ of 60 fantails. $M$. columbinasale was harbored in one $(1.7 \%)$ fantail only. Therefore, $41(68.3 \%)$ of the 60 fantails had one or two 
Table 1. Serological and biochemical properties of reference and isolated strains

\begin{tabular}{|c|c|c|c|c|c|c|c|c|c|c|c|c|}
\hline \multirow[b]{3}{*}{ Species } & \multirow[b]{3}{*}{ Strain } & & & & \multicolumn{8}{|c|}{ Serological test } \\
\hline & & \multicolumn{3}{|c|}{ Biochemical test } & \multicolumn{4}{|c|}{ GI } & \multicolumn{4}{|c|}{ MI } \\
\hline & & Glucose & Arginine & Film \& spots & MMP1 ${ }^{\text {a) }}$ & MMP4 & 694 & $30 \mathrm{~L}$ & MMP1 & MMP4 & 694 & $30 \mathrm{~L}$ \\
\hline \multirow[t]{2}{*}{ M. columbinum } & MMP1 & - & + & + & $4.0^{\mathrm{b})}$ & - & - & - & $256^{\mathrm{c})}$ & .d) & . & . \\
\hline & $28 \mathrm{~L}$ & - & + & + & 4.0 & - & - & - & 256 & . & . & . \\
\hline \multirow[t]{2}{*}{ M. columborale } & MMP4 & + & - & - & - & 3.0 & - & - & . & 128 & . & . \\
\hline & $20 \mathrm{P}$ & + & - & - & - & 3.5 & - & - & . & 64 & . & . \\
\hline \multirow[t]{2}{*}{ M. columbinasale } & 694 & - & + & + & - & - & 3.0 & 4.0 & . & . & 2048 & 102 \\
\hline & $30 \mathrm{~L}$ & - & + & + & - & - & 5.0 & 5.0 & . & . & 1024 & 512 \\
\hline
\end{tabular}

a) Antiserum. b) Growth inhibition zone (mm). c) MI titer. d) MI titer $<2$.

Table 2. Mycoplasma species isolated from oropharynxes of 60 fantails at 2 parks

\begin{tabular}{|c|c|c|c|}
\hline \multirow[b]{2}{*}{ Species isolated } & \multicolumn{2}{|c|}{ Samples $(\%)$} & \multirow[b]{2}{*}{ Total (\%) } \\
\hline & Park F & Park K & \\
\hline M. columbinum & $5(16.7)$ & $13(43.3)$ & $18(30.0)$ \\
\hline M. columborale & $4(13.3)$ & $9(30.0)$ & $13(21.7)$ \\
\hline M. columbinum & & & \\
\hline & $6(20.0)$ & $3(10.0)$ & $9(15.0)$ \\
\hline M. columborale & & & \\
\hline M. columbinum & & & \\
\hline & 0 & $1(3.3)$ & $1(1.7)$ \\
\hline M. columbinasale & & & \\
\hline None & $15(50.0)$ & $4(13.3)$ & $19(31.7)$ \\
\hline Total & $30(100)$ & $30(99.9)$ & $60(100.1)$ \\
\hline
\end{tabular}

species of Mycoplasma. Regarding the number of viable cells, $38(93 \%)$ of 41 samples were in $10^{2}$ colony forming unit $(\mathrm{CFU})$ or more per swab, and the remaining $3(7 \%)$ samples were less than $10^{2} \mathrm{CFU}$ per swab.

It was reported in Japan [11] that $M$. columbinum and $M$. columborale were isolated from $45(69 \%)$ of 65 feral pigeons, but no $M$. columbinasale was detected. These data for feral pigeons are similar in isolation rate to those of the present study of fantails. However, the isolation of $M$. columbinasale reported in the present study is confirmed for the first time in Japan. Ureaplasma gallorale [7] was not detected in this study. Additionally, the prevalence of mycoplasmas between the fantails and the other birds with which they were in close contact was not determined.

Countries other than Japan: Sinclair [12], in England, reported the isolation of $M$. columbinasale from 10 racing pigeons suffering from respiratory disease, and the organisms were eradicated from the pigeons as a result of the administration of tiamurin, an antibiotic. Jordan et al. [4], also in England, isolated $M$. columbinum and $M$. columborale from the esophagus, lung, air sac and brain of feral pigeons, but not $M$. columbinasale. However, other reports from Europe [2, 6, 12] and Australia [9] did reveal the inhabitation of $M$. columbinasale in pigeons. These facts suggest that the prevalence of $M$. columbinasale in pigeons may be different depending on the country or the area.
MacOwan et al. [8], in England, isolated M. columborale from a pigeon infected with a respiratory disease, and the disease was cured by administering an antibiotic. Moreover, the antibody against $M$. columbinum was detected in $11 \%$ of 37 racing pigeons suffering from respiratory disease, but not the antibody against $M$. columborale [6]. These reports suggest that these three species of Mycoplasma are possibly associated with some diseases of pigeons. However, the fact that $M$. gallinarum and $M$. synoviae, two usual inhabitants of chickens, have been isolated from 2 tracheas out of 20 pigeons suffering from respiratory disease [9], and that $M$. columbinasale has been isolated from chickens [1] suggest that pigeons may serve as carriers of poultry diseases. The present and the past reports encourage the etiological investigation of mycoplasmal flora of pigeons in poultry diseases.

\section{REFERENCES}

1. Asnani, P. J. and Agarwal, S. L. 1979. Appl. Microbiol. 27: 997-1000.

2. Howse, J. N. and Jordan, F. T. W. 1983. Vet. Rec. 112: 324326.

3. Jordan, F. T. W., Erno, H., Cottew, G. S., Hinz, K. H., and Stipkovits, L. 1982. Int. J. Syst. Bacteriol. 32: 108-115.

4. Jordan, F. T. W., Howse, J. N., Adams, M. P., and Fatunmbi, O. O. 1981. Vet. Rec. 109: 450.

5. Kelton, W. H. and Van, R. H. 1963. Avian Dis. 7: 272-286.

6. Keymer, I. F., Leach, R. H., Clarke, R. A., Bardsley, M. E., and McIntyre, R. R. 1984. Avian Pathol. 13: 65-74.

7. Koshimizu, K., Harasawa, R., Pan, I.-J., Kotani, H., Ogata, M., Stephens, E. B., and Barile, M. F. 1987. Int. J. Syst. Bacteriol. 37: 333-338.

8. MacOwan, K. J., Jones, H. G. R., Randall, C. J., and Jordan, F. T. W. 1981. Vet.Rec. 109: 562.

9. Reece, R. H., Ireland, L., and Scott, P. C. 1986. Aust. Vet. J. 63: 166-167.

10. Shimizu, T., Erno, H., and Nagatomo, H. 1978. Int. J. Syst. Bacteriol. 28: 538-546.

11. Shimizu, T., Numano, K., and Uchida, K. 1979. Jpn. J. Vet. Sci. 41: 273-282.

12. Sinclair, D. V. 1980. Vet. Rec. 106: 466-467.

13. Yoder, H. W. Jr. and Hofstad, M. S. 1964. Avian Dis. 8: 481512. 